\title{
DOES SCHOOLING REDUCE FAST-START RESPONSE LATENCIES IN TELEOSTS?
}

\author{
P. W. WEBB \\ School of Natural Resources, University of Michigan, Ann Arbor, MI 48109, U.S.A.
}

(Received 24 April 1979)

\begin{abstract}
Response latencies, defined as the time betwecn a d.c. electric shock and initiation of a fast-start (startle response) were measured for eight species of teleosts.

2. Fast-start response latencies varied from 10 to $36 \mathrm{~cm}$. Highest values were found for individuals of two solitary species, Etheostoma caeruleum and Cottus cognatus. Lowest values were found for Esax and Salmo gairdneri.

3. Schooling in Perca flavescens, Lepomis macrochirus and Pimephales promelas significantly reduced fast-start response latencies by $7-16 \mathrm{msec}$. A $4 \mathrm{msec}$. reduction for Notropis cornutus was not significant.

4. No reduction in fast-start response latency was found for Pimephales promelas given the illusion of a school or for individuals greater than $15 \mathrm{~cm}$ from a school.

5. The observed variation in fast-start response latency would favour attack success of predators and escape success for schooled, but not solitary, presumptive prey.
\end{abstract}

\section{INTRODUCTION}

Piscivorous behaviour of fish predators ranges from chasing to ambushing prey. The outcome of any interaction between the predator and the prey fish depends on three factors: (a) relative performance (velocity, acceleration rate); (b) manoeuvre (turning radius); (c) timing (delay in response to a protagonist's manoeuvre); see Howland (1974), Webb (1976) and Elliott et al. (1977). The importance of performance and manoeuvre parameters have been described by Howland (1974) and Elliott et al. (1977). Webb (1976) evaluated the importance of timing in a theoretical treatment of acceleration attacks by piscivores. He concluded that the outcome of such an interaction would depend more on timing than performance or manoeuvre. This was because response latencies were expected to be of the order of 15-25 msec which are long compared to lunging attacks lasting 60-200 msec. (Dill, 1973; Hurley \& Hartline, 1974).
Variation in response latency could therefore have a large effect on vulnerability of prey species. Furthermore, social interactions, such as schooling could affect the response, either by delaying fast-starts due to the noise of other individuals, or reducing delay by preparatory interactions.

The objective of this study was therefore to determine fast-start response latencies of a variety of freshwater teleosts, such as predatory species, forage species, solitary fish and schools.

\section{MATERIALS AND METHODS}

Observations were made on eight species of teleosts (Table 1). Esox and Salmo gairdneri were obtained from local fish hatcheries. Other species were seined from local ponds and streams.

Fish were held in $110 \mathrm{l}$. tanks, continuously flushed with freshwater at $501 . \mathrm{h}^{-1}$. Fish were acclimated to $15^{\circ} \mathrm{C}$ by increasing the water temperature from ambient to $15^{\circ} \mathrm{C}$

Table 1. Total lengths $(\bar{X} \pm 2 \mathrm{SE})$ of species used to measure fast-start response latencies to a d.c. shock stimulus

\begin{tabular}{lcc}
\hline \multicolumn{1}{c}{ Specics } & Length & Notes \\
\hline $\begin{array}{l}\text { Etheostoma caeruleum } \text { Storer } \\
\text { (rainbow darter) }\end{array}$ & $6.2 \pm 0.3$ & Solitary \\
$\begin{array}{l}\text { Cottus hairdi (Girand) } \\
\text { (molted sculpin) }\end{array}$ & $7.5 \pm 0.3$ & Solitary \\
$\begin{array}{l}\text { Salmo gairdneri Richardson } \\
\text { (rainbow trout) }\end{array}$ & $19.5 \pm 1.0$ & $\begin{array}{c}\text { Solitary } \\
\text { at this size } \\
\text { F Esox lucius L. Mitchill }\end{array}$ \\
$\begin{array}{l}\text { D. E. masquinongy } \\
\text { (tiger musky) }\end{array}$ & $21.7 \pm 1.0$ & Solitary \\
$\begin{array}{l}\text { Perca flavescens Mitchill } \\
\text { (yellow perch) }\end{array}$ & $15.5 \pm 0.3$ & Schooling \\
$\begin{array}{l}\text { Lepomis macrochirus Rafinesque } \\
\text { (bluegill) }\end{array}$ & $15.3 \pm 0.6$ & Schooling \\
$\begin{array}{l}\text { Notropis cornutus } \text { Mitchill } \\
\text { (common shiver) } \\
\text { Pimephales promelas Rafinesque } \\
\text { (fathead minnow) }\end{array}$ & $10.7 \pm 1.0$ & Schooling \\
\hline
\end{tabular}


at a rate of $1 \mathrm{C} \cdot \mathrm{day}^{-1}$. Fish were held at $15.0 \pm 0.2 \mathrm{C}$ $\left(\overline{X^{\prime}}+2 \mathrm{SE}\right)$ for a further 2 weeks privr to starting exper $j$ ments. Dissolved oxygen levels were maintained close to air saturation by means of air stones. Fish were fed once a day on Purina trout chow. except for Esox which was fed live minnows.

Individual fish or schools of 10 fish were placed in an observation chamber $50 \mathrm{~cm}$ long. $50 \mathrm{~cm}$ wide and $10 \mathrm{~cm}$ deep. Fish were left undisturbed in the chamber overnight under constant illumination. Next morning, floodlights were slowly turned on using a variable transformer. A brief d.c. electric shock of $1.0 \mathrm{~V} \mathrm{~cm} \mathrm{~cm}^{-1}$ was delivered across the length of the chamber via submerged aluminium grids. An electric shock of this nature has been shown to give similar fast-start response latencies as other stimuli (see Eaton et al. 1977: Webb, 1978). In addition to these experiments, fast-start response latencies were measured for solitary Pimephales promelas in a chamber $10 \mathrm{~cm}$ wide, $50 \mathrm{~cm}$ long and $10 \mathrm{~cm}$ deep, with parallel mirrors covering the full length and depth.

Fast-start responses were recorded on movie film at a framing rate of $500 \mathrm{~Hz}$. and exposure time of $0.75 \mathrm{msec}$. Results for response latencies are therefore accurate to within approx $\pm 2 \mathrm{msec}$. The film record included a stimulus marker and time marker. Films were analyzed frame by frame. The response latency was defined as the time between the stimulus and the beginning of the rapid head flexion of the first stage of the fast-start (Eaton et al., 1977). For schools of fish, separate records were kept of any fish remote from the school.

Mean $\pm 2 \mathrm{SE}$ are shown for all data. Fish groups were compared using Student's $t$-test. Significant differences are declared at the 5" level.

\section{RESUITS}

The response latency for initiation of a fast-start response following a d.c. electric shock varied from
10 to $36 \mathrm{msec}$ among the species tested (Fig. 1). The greatest fast-start response latencies of 32 and 36 msec were found for Etheostoma caeruleum and cottus bairdi respectively, two of the solitary species. The smallest response latencies of $10 \mathrm{msec}$ were found for Esox and Salmo gairdneri. Esox is a specialized piscivore. while fish represent a major diet component for larger salmonids of the size used here (e.g. Scott \& Crossman, 1973). Response latencies for solitary percids and cyprinids ranged from $19-28 \mathrm{msec}$ (Fig. 1)

Fasl-starl response latencies were reduced significantly for individuals in groups for Percu flatescens (24-10 $\mathrm{msec}$; solitary to grouped), Lepomis macrochirus $(28-12 \mathrm{msec})$ and Pimephales promelas (22-15 msec), but not for Notropis cornutus $(20-16 \mathrm{msec})$. The response latency was reduced, but not significantly, for solitary Pimephales swimming between parallel mirrors which would give the illusion of a group. In contrast. Pimephales remote from a group by more than $15-18 \mathrm{~cm}$ ( 3 body lengths) had significantly greater fast-start response latencies than fish in the group. These fast-start response latencies were comparable to those of solitary fish. Therefore. schooling resulted in a marked reduction in fast-start response latency, reducing values for individual fish in schools to the same order as those of typical predators.

The total length of fish used in the experiments varied from 5.6 to $21.7 \mathrm{~cm}$. In the length range $5.6-15.5 \mathrm{~cm}$ there was no relationship between length and fast-start response latency. The two largest species tested were the more pisciviorous species with a lower fast-start response latency. There was therefore no evidence that variations in fast-start response latency were due to differences in size.

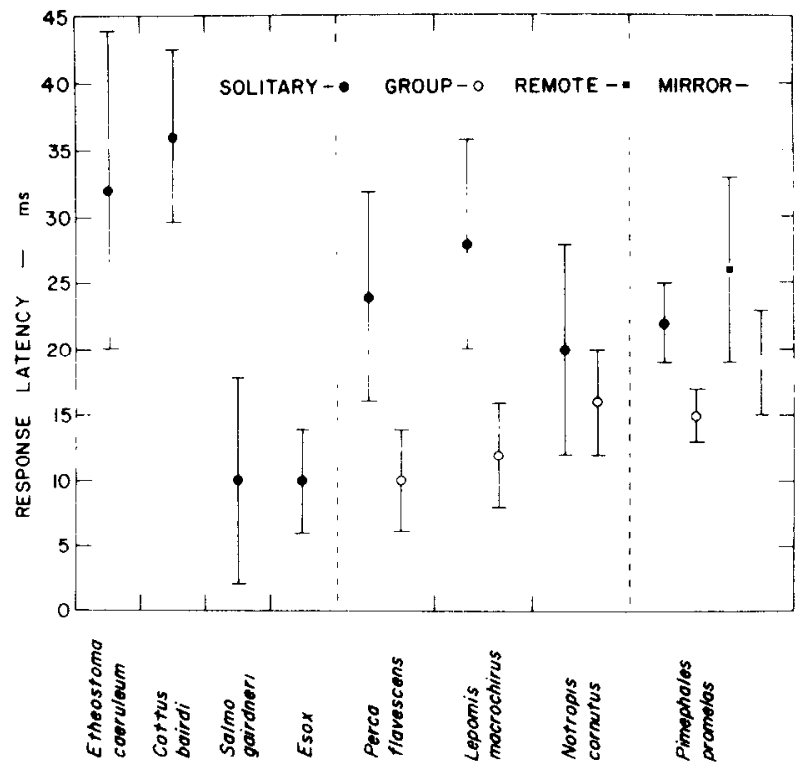

Fig. 1. Fast-start response latencies for eight species of teleosts. Solid circles show data recorded for solitary individuals. open circles for schools of $10 \mathrm{fish}$. Closed squares show response latencies for Individual Pimephales promelas remote from the school by more than $15 \mathrm{~cm}$. Open squares show data for individuals of the same species between parallel mirrors. Vertical bars show $\pm 2 \mathrm{SE}$. 


\section{DISCUSSION}

The fast-start response latencies observed were of the same order as those recorded for individuals of other species. Eaton et al. (1977) obtained values from 5 to $10 \mathrm{msec}$ for 13 teleosts, primarily marine species, at temperatures from 19 to $27^{\circ} \mathrm{C}$. Using the temperature relationship found by Webb (1978) for Salmo gairdneri, these data would be equivalent to $8-16 \mathrm{msec}$ at $15^{\circ} \mathrm{C}$, the temperature used here. Observations on Salmo gairdneri (Webb, 1978) were similar to data for trout obtained here, and to the data from Eaton et al. (1977). Fast-starts initiated by direct stimulation of the Mauthner cell (presumably minimal values) have reported latencies from $14 \mathrm{msec}$ (Russell, 1974) to "tens of milliseconds" (Diamond, 1971). Response latencies for fast-start behaviour are clearly rather variable.

Although there is considerable variation in faststart response latencies, all values observed so far are very much lower than response latencies to nonthreatening stimuli. For example, Hunter (1969) recorded latencies from 120 to $250 \mathrm{msec}$ for jack mackerel (Trachurus symmetricus) responding to movements of other individuals of the same species in the same school.

The overall mean fast-start response latency following d.c. electric shock was $23 \mathrm{msec}$. This response latency was much lower for piscivores and for three out of four species tested in groups. The reduced faststart response latencies are presumed advantageous for both predators and presumptive prey. For example, a short response latency will reduce overshoot error for a predator responding to manoeuvres of elusive prey. Similarly, small fast-start response latencies will be advantageous to prey by reducing the probability of capture. The overall escape probability will be improved because; (a) the probability of an attacking predator striking the prey before significant escape movements are executed will be reduced; (b) the performance differences between protagonists will be reduced for interactions initiated by a lunging predator (Webb, 1976); (c) timing of manoeuvre will be improved during the predator fixed action pattern when predators cannot respond to prey manoeuvre. The latter fixed action pattern appears to be related to opening the mouth, and has a duration of 40-850 msec (Nyberg, 1971; Liem, 1967, 1978). It should also be noted that any advantages accruing to a reduction in fast-start response latencies for fish in groups will be additive to other advantages described for schooling (see Shaw, 1978).

The mechanism whereby fast-start response latencies are reduced for individuals in schools is not known. It is clearly an example of "social facilitation". Group interactions have been shown to be important in a wide variety of behaviours, including feeding (e.g. Olla \& Samet, 1974), sex determination (Robertson, 1972), locomotor activity (Hunter, 1969), growth (Kanda \& Itazawa, 1978), and reproduction (e.g. Travolga, 1976), as well as schooling (e.g. Shaw, 1978). Socially induced neuroanatomical changes in the tectum of jewel fish, Hemichromis bimaculatus (Coss \& Globius, 1978) have been described and provide a possible source of explanation for some of the longerterm group responses. The present short-term effect presumably results from some non-discriminated sensory inputs reducing response thresholds, perhaps at various synapses leading to the Mauthner cell. The data suggest visual sensory input is less important than acoustico-lateralis input. This is because faststart response latencies were (a) reduced for fish a short distance from the school, where near-field disturbances would be damped to some extent and (b) not reduced by an illusion of a group given by mirrors.

The possibility cannot be ruled out that solitary individuals of gregarious species were stressed, resulting in greater fast-start response latencies. For example Parker (1973) found a "calming effect" in several schooling species. Recently handled groups had a lower metabolic rate than recently handled individuals. Similar calming effects are reported by Itazawa et al. (1978). However if stress resulted in large fast-start response latencies, values for normally solitary Etheostoma caeruleum and Cottus bairdi, would be expected to be much lower. Since these species had the highest values, a stress-related explanation for the reduced fast-start response latency for fish in groups seems unlikely.

Acknowledgements -Esox hybrids were kindly supplied by the Michigan Department of Natural Resources. Wolf Lake Hatchery. I wish to thank Dr R. C. Eaton for his comments on the manuscript.

\section{REFERENCES}

Coss R. G. \& Globius A. (1978) Spine stems on tectal interneurons in jewel fish are shortened by social stimulation. Science 200, 787-790.

Diamond J. (1971) The Mauthner cell. In Fish Physiology (Edited by Hoar W. S. \& Randall D. T.), Vol. 6, pp. 265-346.

Dill L. M. (1973) An avoidance learning submodel for a general predation model. Oecologia 13, 291-312.

Eaton R. C., Bombardieri R. A. \& Meyer D. L. (1977) The Mauthner-initiated startle response in teleost fish. J. exp. Biol. 66, 65-81.

Elliott J. P., McTaggart-Cowan I. \& Holling C. S. (1977) Prey capture by the African lion. Can. J. Kool. 55, 1811-1828.

Howland H. C. (1974) Optimal strategies for predator avoidance: the relative importance of speed and manoeuvrability. $J$. theor. Biol. 47, 333-350.

Hunter J. R. (1969) Communication of velocity changes in jack mackerel (Trachurus symmetricus) schools. Anim. Behav. 17, 507-514.

Hurley A. C. \& Hartline P. H. (1974) Escape response in the damselfish Chromis cyanea (Pisces: Pomacentridae): a quantitative study. Anim. Behav. 22, 430437.

Itazawa I., Matsumoto T. \& Kanda T. (1978) Group effects on physiological and ecological phenomena in fish I. Group effect on the oxygen consumption of the rainbow trout and the medaka. Bull. Jap. Soc. Scient. Fish. 44, 965-969.

Kanda T. \& ITAZawa I. (1978) Group effects on physiological and ecological phenomena in fish - II. Group effect on the growth of medaka. Bull. Jap. Soc. Scient. Fish. 44, 1197-1200.

LIEM K. F. (1967) Functional morphology of the head of the anabantoid teleost fish Heleostoma temmincke. $J$. Morph. 121, 135-158.

LIEM K. F. (1978) Modulatory multiplicity in the functional repertoire of the feeding mechanism in cichlid fishes. I Piscivores. J. Morph. 158, 323-360. 
Nyberg D. W. (1971) Prey capture in the largemouth bass. 4m. Midl. Nat. 86, 128-144.

Olla B. L. \& SAmET C. (1974) Fish-to-fish attraction and the facilitation of feeding behavior as mediated by visual stimuli in striped mullet, Mugil cephalus. J. Fish Res. Bd. Can. 31, 1621-1630.

RUSSELL I. J. (1974) Central and peripheral inhibition of lateral live input during the startle response in goldfish. Brain Res. 80. 517--522.

ROBERTSON D. R. (1972) Social control of sex reversal in coral-reef fish. Science 177, 1007-1009.

Scott W. B. \& Crossman E. J. (1973) Freshwater fishes of Canada. Bull. Fish. Re's. Bd. (un 184, 1 96t

Shaw E. (1978) Schooling fishes. Am. Sicent. 66, 160 175

Tavolga W. N. (1976) Chemical stimuli in the reproductive behavior in fish: communication. Experienta 32, 1093-1095

WebB P. W. (1976) The effect of size on the fast-start performance of rainbow trout Salmo yalrdneri, and a consideration of piscivorous predator-prey interactions. I exp. Biol. 65, $157-177$.

WeBr P. W. (1978) Temperature effects on acceleration of rainbow trout. Salmo gairdneri. J. Fish. Re's. Bd. Can. 35 , 14171422 